\title{
SISTEM SELF ASSESSMENT PEMUNGUTAN BEA PEROLEHAN HAK ATAS TANAH DAN BANGUNAN YANG BERBASIS ESTIMASI DI KOTA BANDUNG DIKAITKAN DENGAN ASAS KEPASTIAN HUKUM
}

\author{
Hendra Carmana \\ Fakultas Hukum Magister Kenotariatan Universitas Islam Bandung \\ hendracarmana@yahoo.com \\ DOI : https://doi.org/ 10.29313/shjih.v18i2.6437
}

\begin{abstract}
Abstrak
Bea Perolehan Hak atas Tanah dan Bangunan merupakan pemungutan pajak yang awalnya merupakan pajak pusat yang kini beralih menjadi pajak daerah berdasarkan Undang-Undang Nomor 28 Tahun 2009 Tentang Pajak Daerah dan Retribusi Daerah yang bertujuan meningkatkan Anggaran Pendapatan Daerah. Hasil penelitian menunjukan bahwa praktek di lapangan pemungutan BPHTB tidak sesuai dengan sistem Self Assessment bahkan lebih cenderung kepada sistem Official Assessment, hal tersebut dikarenakan adanya ketidakpercayaan terhadap wajib pajak dalam menyampaikan transaksi yang mereka lakukan sehingga untuk mendapatkan nilai transaksi yang mendekati sebenarnya petugas BPPD Kota Bandung dan mengeluarkan nota verifikasi sebagai nilai transaksi serta adanya tuntutan bahwa setiap petugas pajak dari masing-masing daerah diberikan target dalam hal pemasukan kedalam pendapatan daerah, sehingga dalam hal tersebut terdapat inkonsistensi dalam implementasi sistem Self Assessment. Adanya Estimasi dan Validasi menimbulkan ketidakpastian hukum terhadap transaksi peralihan hak yang dilakukan dan juga memperpanjang rantai proses yang harus ditempuh oleh Pihak Notaris/PPAT, maupun oleh pihak penjual dan pembeli sebagai wajib pajak, sebelum akan dilakukan proses penandatangan peralihan hak.
\end{abstract}

Kata Kunci: BPHTB, self assessment, kepastian hukum

\begin{abstract}
Tax on Acquisition of Land and Building a tax collection was originally the central tax now turned into a local tax based on Law Number 28 Year 2009 on Regional Taxes and Levies which aims to increase the budget of Revenue. The final conclusion is that the practice in the field collecting BPHTB not in accordance with the system of self assessment are even more likely to systems Official Assessment, it is because of their distrust of the taxpayer in delivering transactions that they do so to get the transaction value approaching actually officer BPPD Bandung will estimate without field checks (verification field) and issued a memorandum of verification as the value of the transaction as well as their demands that any taxing authority of each region is given a target in terms of revenues into revenues, so in that respect there are inconsistencies in the implementation of the system of Self Assessment. Then the Estimation and Validation of legal uncertainty to transactions carried out and the transfer of rights also extend the chain of processes that must
\end{abstract}


be taken by the Party Notary / PPAT, or by the seller and the buyer as a taxpayer, prior to the signing of the transition will be done right.

Keywords: BPHTB, self-assessment, legal certainty.

\section{A. PENDAHULUAN}

Pembangunan yang produktif tersebut dapat dicapai melalui pemerintah pusat maupun melalui pemerintah daerah. Adapun tujuan yang dicapainya pembangunan di pemerintah daerah tersebut. Berdasarkan Undang-Undang Republik Indonesia Nomor 23 Tahun 2014 Tentang Pemerintahan Daerah bahwa penyelenggaraan pemerintahan daerah diarahkan untuk mempercepat terwujudnya kesejahteraan masyarakat melalui peningkatan pelayanan, pemberdayaan dan peran serta masyarakat, serta peningkatan daya saing daerah dengan memperhatikan prinsip demokrasi, pemerataan, keadilan, dan kekhasan suatu daerah dalam sistem Negara Kesatuan Republik Indonesia. ${ }^{1}$

Pelaksanaan program pembangunan tersebut memerlukan dana pembangunan yang cukup besar yang diperoleh dari berbagai bentuk penerimaan negara yang dihimpun dalam bentuk tabungan pemerintah, adapun salah satu sumber penerimaan negara tersebut adalah berasal dari sektor pajak. Demikian juga untuk pembangunan yang dilaksanakan oleh pemerintah daerah, pajak merupakan sumber pembiayaan yang sangat penting. Hal tersebut didukung dengan dibentuknya Undang-Undang Republik Indonesia Nomor 28 Tahun 2009 Tentang Pajak Daerah dan Retribusi Daerah (UU PDRD) yang menyatakan bahwa pajak daerah dan retribusi daerah merupakan salah satu sumber pendapatan daerah yang penting guna membiayai pelaksanaan pemerintah daerah. Berdasarkan Pasal 1 angka 10 UU PDRD, Pajak adalah kontribusi wajib kepada Daerah yang terutang oleh orang pribadi atau badan yang bersifat memaksa berdasarkan Undang-Undang, dengan tidak mendapatkan imbalan secara langsung dan digunakan untuk keperluan Daerah bagi sebesar-besarnya kemakmuran rakyat.

${ }^{1}$ Rusdianto, Hukum Otonomi Daerah, Refika Aditama, Bandung, 2012, hlm 15 
Berdasarkan UU PDRD salah satu jenis pajak daerah Kabupaten/Kota adalah Bea Perolehan Hak atas Tanah dan Bangunan (BPHTB) yang dikenakan atas perolehan hak atas tanah dan bangunan, yaitu perbuatan atau peristiwa hukum yang mengakibatkan diperolehnya hak atas tanah dan/atau bangunan oleh orang pribadi atau badan. BPHTB merupakan salah satu pajak obyektif atau pajak kebendaan yang pajak terutangnya didasarkan pertama-tama pada apa yang menjadi obyek pajak baru kemudian memperhatikan siapa yang menjadi subyek pajak. ${ }^{2}$ BPHTB merupakan pemungutan pajak yang awalnya merupakan pajak pusat yang kini beralih menjadi pajak daerah yang berpotensi meningkatkan Pendapatan Anggaran Daerah.

Salah satu objek pajak BPHTB yakni pemindahan hak karena adanya jual beli. Transaksi jual beli tanah dan/atau bangunan merupakan suatu aktivitas yang dilakukan oleh masyarakat yang dapat memberikan pemasukan berupa pajak dalam jumlah yang relatif besar bagi daerah, karena jual beli merupakan suatu perbuatan hukum yang dapat menimbulkan hutang pajak. Di setiap daerah telah ditentukan bagaimana tata cara pemungutan BPHTB agar daerah tetap mendapatkan dana untuk pembangunan pemerintah bagi kepentingan masyarakat. ${ }^{3}$

Salah satu daerah yang menjalankan ketentuan Perpajakan BPHTB dalam pemerintah daerahnya adalah Kota Bandung, dalam pelaksanaan peralihan Hak terutama dalam pemungutan BPHTB, dengan dibentuknya Peraturan Walikota Nomor 393 Tahun 2012 tentang Tata Cara Pemungutan Pajak Daerah dan Peraturan Walikota Bandung Nomor 1405 Tahun 2016 Tentang Kedudukan Susunan Organisasi, Tugas Dan Fungsi Serta Tata Kerja Badan Pengelola Pendapatan Daerah Kota Bandung.

Berdasarkan Pasal 1 ayat (9) Peraturan Walikota Nomor 393 Tahun 2012, pengertian Pajak Daerah yang selanjutnya disebut pajak adalah kontribusi wajib

\footnotetext{
${ }^{2}$ Marihot P. Siahaan, Bea Perolehan Hak Atas Tanah dan Bangunan, Teori dan Praktik, PT. Raja Grafindo, Jakarta, 2005, hlm. 44.

${ }^{3}$ Budi Ispriyaso, Aspek Perpajakan dalam Pengalihan Hak Atas Tanah dan/atau Bangunan karena Adanya Transaksi Jual Beli, Masalah-masalah Hukum, Volume 14, Mitra Bakti, 2005, hlm. 277.
} 
kepada Daerah yang terutang oleh orang pribadi atau badan yang bersifat memaksa berdasarkan Undang-Undang dengan tidak mendapatkan imbalan secara langsung dan digunakan untuk keperluan daerah bagi sebesar-besarnya kemakmuran rakyat.

Berdasarkan dengan ciri-ciri Self Assessment dalam BPHTB yang merujuk Pasal 4 Peraturan Pemerintah Republik Indonesia Nomor 91 Tahun 2010 Tentang Jenis Pajak Daerah Yang Dipungut Berdasarkan Penetapan Kepala Daerah Atau Dibayar Sendiri Oleh Wajib Pajak Juncto Pasal 3 ayat (4) Peraturan Pemerintah Republik Indonesia Nomor 55 Tahun 2016 Tentang Ketentuan Umum Dan Tata Cara Pemungutan Pajak Daerah.

Di Indonesia telah mengalami beberapa perubahan dalam penerapan sistem pemungutan pajak mulai dari sistem official assessment, sistem semi self assessment, sistem withholding dan sistem self assessment. ${ }^{4}$

Sistem cara pemungutan pajak BPHTB tersebut mencerminkan pemungutan secara self assessment system. Self assessment system adalah sistem pemungutan pajak yaitu wajib pajak menentukan sendiri jumlah pajak yang terutang sesuai dengan ketentuan undang-undang perpajakan.

Dalam tata cara ini kegiatan pemungutan pajak diletakan pada aktivitas masyarakat itu sendiri yaitu wajib pajak diberi kepercayaan untuk: ${ }^{5}$

1. Menghitung sendiri pajak yang terutang;

2. Memperhitungkan sendiri pajak yang terutang;

3. Membayar sendiri pajak yang harus dibayar;

4. Melaporkan sendiri jumlah pajak yang terutang;

5. Fiskus tidak ikut campur dan hanya mengawasi.

${ }^{4}$ Toyyibatuz Zaimah, Efektivitas Self Assessment Dalam Pajak Penghasilan di Kantor Pelayanan Pajak Pratama Batu (Perspektif Hukum Positif dan Hukum Islam), Jurusdictie: Jurnal Hukum dan Syariah Vol. 7 No. 1 Tahun 2016., hlm. 45.

${ }^{5}$ Mardiasmo, Perpajakan Edisi 4, Andi, Yogyakarta, 1997, hlm. 8. 
Syarat self assessment system dapat berhasil dengan baik apabila adanya perhitungan yang sederhana, pelaksanaan yang mudah, lebih adil dan merata, dan perhitungan pajak dilakukan oleh wajib pajak itu sendiri. ${ }^{6}$

Sistem self assessment ini mewajibkan wajib pajak untuk menentukan besaran pajak yang harus dibayarkan, menghitung dan melaporkan sendiri BPHTB ke kas Negara/kas daerah, fiskus hanya menetapkan Nilai Pokok Objek Tidak Kena Pajak (NPOPTKP) dan tarif BPHTB untuk dijadikan dasar perhitungan besarnya BPHTB yang harus dibayar. Sehingga dalam hal ini pemerintah daerah tidak perlu ikut campur dalam menentukan pembayaran pajak BPHTB.

Fungsi penghitungan merupakan fungsi pertama bagi Wajib Pajak untuk menentukan berapa besarnya pajak terutang. Untuk melaksanakan fungsi ini Wajib Pajak harus mengetahui mengenai peraturan perpajakan yang berlaku, karena dasar untuk menentukan besarnya PKP (Penghasilan Kena Pajak) adalah peraturan perpajakan. $^{7}$

Dalam praktiknya ternyata justru wajib pajak pasif (tidak aktif) dan pemerintah daerah (sebagai fiskus) sangat aktif dan dominan. Salah satu contohnya adalah pada Badan Pengelolaan Pendapatan Daerah (BPPD) Pemerintah Kota Bandung. Hal ini terlihat dari berbagai tindakan yang dilakukan fiskus, yaitu melakukan penetapan nilai transaksi yang akan dibayarkan, melakukan verifikasi terhadap nilai transaksi yang dibuat para pihak, sehingga justru menunjukan pelaksanaan pemungutan pajak dengan sistem Official Assessment. Ditambah di sisi penjual dalam melakukan pembayaran Pajak Penghasilan (PPh) yang telah dibayarkan ke kas Negara dan akan melakukan validasi PPh ke Kantor Pelayanan Pajak Pratama (KPP), ternyata KPP menetapkan kembali nilai transaksi dan nilai pajak yang harus dibayarkan oleh pihak penjual, sehingga dalam hal ini terdapat 3 (tiga) nilai transaksi yaitu:

${ }^{6}$ Adrian Sutedi, Hukum Pajak, Sinar Grafika, Jakarta, 2016, hlm. 13.

${ }^{7}$ Tarjo dan Indra Kusumawati, Analisis Perilaku Wajib Pajak Orang Pribadi Terhadap Pelaksanaan Self Assessment System: Suatu Studi Di Bangkalan, JAAI Volume 10, No. 1 Juni 2006: 101-120, hlm. 106. 
1. Nilai transaksi real (yang sebenarnya);

2. Nilai yang ditetapkan oleh Dinas Pelayanan Pajak Daerah;

3. Nilai yang ditetapkan oleh Kantor Pelayanan Pajak (KPP).

Sehingga terlihat sekali ketidakpastian hukum dalam menjalankan pemungutan pajak, serta untuk Notaris/Pejabat Pembuat Akta Tanah (PPAT) merasakan kebingungan nilai mana yang harus dijadikan dasar pengenaan dalam pajak dalam Peralihan hak termasuk dalam Pelepasan Hak Atas Tanah dan Akta Jual Beli (AJB).

Adanya penggunaan nilai transaksi sebagai dasar perhitungan BPHTB inilah yang sering kali menimbulkan permasalahan di lapangan, karena tidak jarang nilai transaksi yang diajukan oleh wajib pajak dianggap tidak sesuai ${ }^{8}$ oleh petugas BPPD, sehingga tidak jarang petugas BPPD dalam proses pengajuan Nota Verifikasi meminta kepada wajib pajak untuk disesuaikan menurut nilai estimasi dari petugas BPPD, yang menurut mereka petugas BPPD nilai estimasi tersebut adalah nilai wajar atau harga pasar untuk wilayah tersebut.

Verifikasi merupakan penelitian berkas-berkas kelengkapan yang diberikan oleh wajib pajak dan menghitung kewajiban BPHTB yang harus dibayarkan oleh wajib pajak, yang akhirnya menjadi dasar untuk mengetahui besaran pembayaran BPHTB. Verifikasi dilakukan oleh Petugas Pemeriksa yang dituangkan dalam bentuk Nota Verifikasi.

Verifikasi dilakukan dikarenakan masih banyak masyarakat yang ingin membayar pajak ringan, sehingga nilai yang dicantumkan dalam akta dan yang digunakan sebagai dasar pembayaran pajak adalah nilai perhitungan BPHTB tidak sesuai dengan kenyataan yang sebenarnya yang telah disetujui oleh para pihak.

Dalam hal terjadi pemaksaan dan/atau suatu tindakan yang mengakibatkan nilai transaksi tidak sesuai dengan kenyataan yang telah disepakati oleh para pihak, maka

${ }^{8}$ R. Murjiyanto dan Samun Ismaya, Kepastian Nilai Dasar Penghitungan Bea Perolehan Hak Atas Tanah dan Bangunan (BPHTB), https://media.neliti.com/media/publications/84800-ID-kepastiannilai-dasar-penghitungan-bea-p.pdf, diunduh tanggal 16 Mei 2019 pukul 20.36 WIB 
transaksinya dapat menjadi tidak sah. ${ }^{9}$ Kesepakatan dan/atau perjanjian itu timbul karena kebutuhan dan perkembangan di masyarakat didasari oleh asas kebebasan berkontrak. ${ }^{10}$

Dengan adanya ketentuan penggunaan nota verifikasi BPHTB tersebut mengakibatkan tugas yang dilakukan oleh pihak Notaris/PPAT menjadi terhambat, sehingga pelayanan pembuatan akta jual beli dan proses peralihan hak atas tanah tersebut menjadi lebih lama dikarenakan diharuskannya melewati prosedur pembuatan nota verifikasi tersebut dikarenakan kurang pahamnya masyarakat dalam pembuatan nota verifikasi tersebut dan juga ketidakpastian atas nilai transaksi jual beli dikarenakan munculnya penentuan nilai estimasi yang ditentukan oleh petugas BPPD.

Tanah dan bangunan menjadi lebih bernilai karena dapat dialihkan dari pemiliknya kepada pihak lain yang menginginkannya. Peralihan hak atas tanah dan bangunan berkaitan erat dengan kepastian hukum dan ditandai oleh adanya bukti atas peralihan hak tersebut. Untuk memberikan kekuatan dan kepastian hukum pemilikan tanah dan bangunan, setiap peralihan hak atas tanah dan/atau bangunan harus dilakukan sesuai dengan hukum yang rnengaturnya. Perolehan hak sebagai hasil peralihan hak harus dilakukan secara tertulis dengan akta yang dibuat oleh pejabat yang berwenang, serta wajib didaftarkan pada instansi yang berwenang, yaitu kantor pertanahan Kabupaten/Kota setempat. Dengan demikan, hak alas tanah dan bangunan secara sah ada pada pihak yang rnemperoleh hak tersebut dan dapat dipertahankan terhadap semua pihak.

Proses peralihan hak atas tanah dan/atau bangunan hanya dapat dilakukan apabila wajib pajak telah menyerahkan bukti setor pembayaran pajak. Hal ini

\footnotetext{
${ }^{9}$ Adimas Wahyu Widayat, Analisis Pengenaan Bea Perolehan Hak Atas Tanah Dan Bangunan Dalam Proses Jual Beli Tanah dan Bangunan di Kabupaten Kebumen, Jurnal Lex Renaissance, Vol. 1 No. 2, Juli 2016, hlm. 167.

${ }^{10}$ Wiratni Ahmadi, et.al., Teknik Pembuatan Akta Notaris, Logoz Publishing, Bandung, 2016, hlm. 12 .
} 
ditegaskan dalam Pasal 91 ayat (1) Undang-Undang Nomor 28 Tahun 2009 Tentang Pajak Daerah dan Retribusi Daerah yang menyatakan :

"Pejabat Pembuat Akta Tanah/Notaris hanya dapat menandatangani akta pemindahan Hak atas Tanah dan/atau Bangunan setelah Wajib Pajak menyerahkan bukti pembayaran pajak".

Berdasarkan latar belakang masalah penelitian diatas, peneliti dalam hal ini mengidentifikasikan beberapa masalah sebagai berikut: Pertama, implementasi sistem Self Assessment dalam pemungutan BPHTB menurut Undang-Undang Nomor 28 Tahun 2009 Tentang Pajak Daerah dan Retribusi Daerah. Kedua, Kepastian hukum penetapan BPHTB dalam pelaksanaan peralihan hak berkaitan dengan adanya kewajiban Estimasi dan Validasi BPHTB oleh Pemerintah Kota Bandung.

\section{B. METODE PENELITIAN}

Metode Penelitian yang digunakan adalah metode penelitian yuridis normatif yang bersifat kualitatif. Metode penelitian yuridis normatif digunakan untuk meneliti dan mengkaji data sekunder yang berkaitan dengan implementasi sistem self assessment terhadap BPHTB. Spesifikasi/sifat penelitian ini adalah deskriptif analitis, yaitu menggambarkan pelaksanaan pemungutan BPHTB di BPPD Kota Bandung serta menganalisis permasalahan tersebut dalam kaitannya dengan implementasi sistem self assestment terhadap BPHTB dalam peralihan hak yang berbasis estimasi di Kota Bandung yang dikaitkan dengan asas kepastian hukum. Kemudian gambaran umum tersebut dianalisis dengan bertitik tolak dari perundang-undangan, teori-teori yang ada dan pendapat para ahli yang bertujuan untuk mencari dan mendapatkan jawaban dari pokok masalah yang akan dibahas lebih lanjut.

\section{PEMBAHASAN}




\section{Implementasi Sistem Self Assessment Dalam Pemungutan BPHTB menurut Undang-Undang Nomor 28 Tahun 2009 tentang Pajak Daerah dan Retribusi Daerah}

BPHTB yang merupakan pajak yang dikenakan secara insidential, artinya utang pajak timbul dengan sendirinya ketika dipenuhinya tatbestand (keadaan, peristiwa dan keadaan) tanpa menunggu adanya surat ketetapan pajak dari fiskus. Untuk menguji kepatuhan para wajib pajak dalam melaksanakan kewajiban perpajakannya sehingga diperlukan pengawasan dari pihak pemerintah daerah dalam bentuk pemeriksaan. ${ }^{11}$

Berdasarkan Pasal 91 ayat (1) UU PDRD terdapat prinsip yang diatur tentang BPHTB adalah Pejabat Pembuat Akta Tanah/Notaris hanya dapat menandatangani akta pemindahan hak atas tanah dan/atau bangunan setelah wajib pajak menyerahkan bukti pembayaran pajak, yang memberikan pemahaman bahwa wajib pajak melakukan perhitungan dan membayar pajak itu sesuai dengan perhitungannya sendiri, sehingga perbuatan tersebut merupakan ciri-ciri dari Self Assessment System, demikian pula berdasarkan Pasal 4 Peraturan Pemerintah Nomor 91 Tahun 2010 Tentang Jenis Pajak Daerah Yang Dipungut Berdasarkan Penetapan Kepala Daerah Atau Dibayar Sendiri Oleh Wajib Pajak Juncto Pasal 3 ayat (4) Peraturan Pemerintah Nomor 55 Tahun 2016 Tentang Ketentuan Umum Dan Tata Cara Pemungutan Pajak Daerah, bahwa BPHTB merupakan jenis pajak kabupaten/kota yang dibayar sendiri berdasarkan perhitungan oleh wajib pajak.

Ciri-ciri Self Assessment System dijelaskan dalam penjelasan UndangUndang Nomor 20 Tahun 2000 Tentang BPHTB Pasal 10 ayat (1), yang menyatakan bahwa sistem pemungutan Bea Perolehan Hak Atas Tanah dan Bangunan adalah Self Assessment System dimana wajib pajak diberi kepercayaan untuk menghitung dan membayar sendiri pajak terutangnya dengan menggunakan Surat Setoran Bea Perolehan Hak Atas Tanah dan

${ }^{11}$ Marihot, Bea Perolehan Hak Atas Tanah dan Bangunan Teori dan Praktik, Edisi Revisi, Rajawali Pers, Jakarta, 2003, hlm. 170. 
Bangunan, dan melaporkannya tanpa mendasarkan diterbitkannya Surat Ketetapan Setoran Pajak. Dilihat dari alur sistem pemungutannya, pemungutan BPHTB yang diterapkan di Pemerintah daerah Kota Bandung belum sesuai dengan Self Assessment System.

Sebab kondisi yang terjadi atau faktanya di lapangan, alur sistem pemungutan BPHTB yang diterapkan lebih cenderung menggunakan Official Assessment System, dengan demikian akibat hukum yang terjadi dalam sistem pemungutan pajak BPHTB ini, yaitu tidak adanya kepastian hukum antara peraturan perundang-undangan yang ada dan bentuk implementasi dalam sistem self assessment itu sendiri. Berikut penyebab yang terjadi terhadap persoalan tersebut dan kondisi yang terjadi:

1. Berdasarkan hasil wawancara peneliti dengan $X X$, salah seorang staf dari Dinas Pelayanan Pajak Kota Bandung Bagian Penerimaan dan Pemeriksaan BPHTB, dalam prakteknya banyak dari wajib pajak tidak jujur mengemukakan Nilai Perolehan Objek Pajak (NPOP) yang berasal dari nilai transaksi kepada Dinas Pelayanan Pajak atau dalam mengisi SSPD BPHTB. Bahkan NJOP lebih sering diajukan sebagai dasar pengenaan pajak dalam SSPD BPHTB. Hal tersebut dilakukan wajib pajak tentunya dengan maksud mengurangi jumlah BPHTB terutang. ${ }^{12}$

2. Selanjutnya XX, menjelaskan Dinas Pelayanan Pajak Kota Bandung menerapkan sistem praduga tidak benar terhadap setiap SSPD BPHTB yang dilaporkan oleh wajib pajak, sehingga setiap SSPD BPHTB yang masuk/dilaporkan akan diperiksa dan diteliti dengan seksama. Dalam hal ini ketika dilakukan penelitian SSPD BPHTB oleh petugas peneliti, apabila menimbulkan kecurigaan adanya indikasi ketidakjujuran dari wajib pajak, maka Dinas akan melakukan verifikasi lapangan. Verifikasi lapangan dilakukan untuk mengetahui NPOP (nilai transaksi dan nilai pasar), karena

${ }^{12}$ Wawancara dengan XX, staf dari Dinas Pelayanan Pajak Kabupaten Bandung Bagian Penerimaan dan Pemeriksaan BPHTB, pada tanggal 04 Nopember 2019. 
sebisa mungkin pemerintah daerah menggunakan NPOP sebagai dasar pengenaan pajak bukan NJOP.

Menurut XX, untuk mendapatkan nilai transaksi riil dalam transaksi jual beli misalnya, upaya yang ditempuh oleh petugas verifikasi lapangan adalah berusaha mendapatkan informasi nilai transaksi dari penjual, atau dari masyarakat sekitar, namun apabila nilai transaksi sulit didapatkan, petugas verifikasi lapangan mencari informasi tentang nilai pasar, yang mana nilai pasar tersebut diatas NJOP dan dianggap oleh Dinas Pelayanan Pajak mendekati dengan nilai transaksi riil. Pencarian informasi tentang nilai pasar dilakukan Dinas Pelayanan Pajak dengan melibatkan aparatur desa/kelurahan dan instansi vertical di daerah. Nilai pasar sendiri ditentukan oleh Dinas Pelayanan Pajak setelah mendapatkan informasi nilai transaksi terbesar dan terkecil di wilayah tersebut.

3. Berdasarkan wawancara peneliti dengan $\mathrm{XX}$ selaku petugas pemeriksa berkas dan yang menetapkan nilai transaksi di wilayah Kota Bandung, terdapat faktor bahwa dalam rangka untuk pengembangan daerah Kota Bandung, dari sektor BPHTB ini setiap petugas pajak diberikan target dalam hal pemasukan yang harus diterima oleh pemerintah Kota Bandung, sehingga ini merupakan salah satu penyebab pemerintah Kota Bandung melakukan penetapan atau memberikan Nota Verifikasi kepada setiap wajib pajak, serta banyak juga wajib pajak yang tidak jujur dalam memasukan nilai transaksi yang sebenarnya, sehingga pemerintah Kota Bandung mengeluarkan nilai estimasi atau nota verifikasi.

4. Dalam hal pemberian informasi kepada wajib pajak terkadang berbeda, sehingga terjadi ketidakjelasan dalam hal pembayaran pajak BPHTB, dalam hal ini pemerintah daerah melalui Dinas Pelayanan Pajak mengeluarkan nota verifikasi atau nilai estimasi yang artinya pemerintah daerah menetapkan nilai transaksi dalam menentukan berapa pajak BPHTB yang harus dibayarkan oleh wajib pajak, sehingga dalam hal ini terdapat 2 (dua) nilai transaksi yaitu : 1. Nilai transaksi real (yang sebenarnya), 2. Nilai yang 
ditetapkan oleh Dinas Pelayanan Pajak. Sehingga terlihat sekali ketidakpastian hukum dalam menjalankan pemungutan pajak BPHTB.

Berikut peneliti menjabarkan tahap-tahap dalam sistem pemungutan Bea Perolehan Hak Atas Tanah dan Bangunan (BPHTB) :

1. Mengisi formulir BPHTB;

2. Melengkapi persyaratan pengajuan verifikasi;

3. Mengajukan nilai transaksi;

4. Memperoleh hasil nota verifikasi atau estimasi;

5. Membayar BPHTB sesuai dengan nota verifikasi atau estimasi; dan

6. Melakukan validasi kepada Dinas Pelayanan Pajak.

Sebagaimana yang telah dijabarkan diatas bahwa terdapat persoalan dan kondisi yang terjadi sehingga dalam pemungutan pajak BPHTB belum tercapai self assessment system, berikut analisis peneliti:

1. Dari sisi yuridis, bahwa dalam prakteknya banyak dari wajib pajak tidak jujur mengemukakan Nilai Perolehan Objek Pajak (NPOP) yang berasal dari nilai transaksi kepada Dinas Pelayanan Pajak atau dalam mengisi SSPD BPHTB. Bahkan NJOP lebih sering diajukan sebagai dasar pengenaan pajak dalam SSPD BPHTB. hal tersebut dilakukan wajib pajak tentunya dengan maksud mengurangi jumlah BPHTB terutang.

Dalam praktek di lapangan, dari hasil penelitian dan verifikasi lapangan Dinas Pelayanan Pajak cukup sering mengeluarkan SKPDKB, namun sebagian wajib pajak lainnya tidak mematuhi dan tidak membayar kekurangan pembayaran tersebut sesuai dengan jangka waktu yang telah ditentukan. Dalam hal ini Dinas Pelayanan Pajak belum pernah mengeluarkan surat teguran ataupun surat paksa kepada wajib pajak yang tidak mematuhi Surat Ketetapan Pajak Kurang Bayar tersebut, dengan alasan Dinas Pelayanan Pajak merasa masih mempunyai waktu daluarsa sampai dengan 5 (lima) tahun untuk melakukan penagihan pajak. Wajib pajak sebagian besar masih banyak mencantumkan NJOP sebagai Dasar Pengenaan Pajak. 
Hal tersebut dilakukan karena adanya faktor ketidaktahuan masyarakat/wajib pajak dalam menerapkan harga pasar.

2. Berdasarkan Peraturan Walikota Bandung Nomor 393 Tahun 2012 Tentang Tata Cara Pemungutan Bea Perolehan Hak Atas Tanah dan Bangunan, sebab lain diadakannya verifikasi lapangan oleh Dinas Pelayanan Pajak selain untuk menguji kebenaran atas harga transaksi yang tercantum dalam SSPD BPHTB dengan harga yang berlaku di pasaran, juga untuk menguji kebenaran data luas tanah (bumi) dan/atau bangunan yang tercantum dalam SSPD BPHTB dengan keadaan yang sebenarnya di lapangan. Namun verifikasi lapangan yang selama ini dilakukan oleh Dinas Pelayanan Pajak baru verifikasi yang bertujuan untuk menguji kebenaran atas harga transaksi/nilai pasar saja yang dapat dilakukan, sedangkan pelaksanaan verifikasi lapangan yang memerlukan pengukuran luas tanah dan/atau bangunan belum sepenuhnya dapat dilakukan karena keterbatasan jumlah petugas verifikasi lapangan dan belum dibekalinya petugas dengan kemampuan menilai suatu bangunan.

3. Penerimaan negara dari sektor pajak dapat dikategorikan sebagai perwujudan dari asas efisiensi, yaitu pemungutan pajak harus dikenakan pada saat dan cara yang paling baik, tepat, sesuai dan menyenangkan bagi wajib pajak pada umumnya, karena bagaimanapun juga pemerintah mempunyai kewajiban untuk menjaga dan melindungi kepentingan rakyatnya, menjamin keamanan jiwa, raga dan harta benda rakyatnya, hal ini sesuai dengan pemahaman maxim keempat Adam Smith yaitu perwujudan yang efisiensi. Dan maxim ketiga Adam Smith melalui asas convenience of payment yaitu pemungutan pajak yang baik dan benar. Berdasarkan pemikiran tersebut, maka ketentuan yang mengatur pemungutan pajak BPHTB itu sebaiknya tidak harus memenuhi asas-asas pemungutan pajak sebagaimana dikemukakan oleh Adam Smith dalam bukunya "wealth of nations" yang dikenal dengan four canon taxation" atau sering disebut The Four Maxims, yaitu asas Equality (persamaan), asas 
Certainty (kepastian), asas convenience of payment (menyenangkan), dan asas efficiency (efisien).

4. Dihubungkan dengan pendapat Mochtar Kusumaatmadja mengenai pajak secara keseluruhan, hukum merupakan sarana pembaharuan dalam masyarakat, sehingga hukum perlu dibangun secara berencana agar hukum sebagai sarana pembaharuan dalam masyarakat dapat berjalan secara serasi, seimbang, selaras sehingga kehidupan hukum mencerminkan keadilan, kemanfaatan sosial dan kepastian hukum. ${ }^{13}$

Dengan demikian tujuan hukum sebagai sarana pembaharuan dan pembangunan masyarakat yang sedang membangun, hukum harus dapat membantu proses perubahan masyarakat tersebut. ${ }^{14}$

Ketika BPHTB masih dipungut oleh Kantor Pelayanan Pajak (KPP), pencantuman dan perhitungan BPHTB terutang berdasarkan NJOP sebagai dasar pengenaan pajak tidak menjadi masalah, namun sekarang semenjak BPHTB dipungut oleh Dinas Pelayanan Pajak, nampaknya Dinas Pelayanan Pajak berusaha keras menerapkan NPOP yang berasal dari nilai transaksi/nilai pasar sebagai Dasar Pengenaan Pajak. Jadi apabila wajib pajak mencantumkan NJOP sebagai Dasar Pengenaan Pajak, Dinas Pelayanan Pajak akan melakukan verifikasi lapangan dan kemungkinan besar Dinas Pelayanan Pajak akan mengeluarkan SKPDKB, karena memang NJOP-nya dibawah harga transaksi/hasil pemeriksaan yang dilakukan baik oleh petugas peneliti ataupun oleh petugas verifikasi lapangan dan apabila ternyata terbukti bahwa wajib pajak kurang membayar BPHTB maka dapat dikeluarkannya Surat Ketetapan Pajak Kurang Bayar (SKPDKB) dengan jangka waktu pelunasan selama 30 (tigapuluh) hari. Apabila dalam jangka waktu tersebut wajib pajak tidak

${ }^{13}$ Mochtar Kusumaatmadja dan Lilian Tedjosaputro, Etika ProfesiDalam Penegakan Hukum Pidana, Bigraf Publishing, Yogyakarta, 1994, hlm. 4.

${ }^{14}$ Mochtar Kusumaatmadja, Konsep-Konsep Hukum Dalam Pembangunan, Alumni, Bandung, 1995, hlm. 13. 
melunasi BPHTB terutang sesuai dengan SKPDKB maka Dinas Pelayanan Pajak akan mengeluarkan surat teguran dan surat paksa.

Tata cara pemungutan pajak dengan menggunakan self assessment berhasil dengan baik jika masyarakat mempunyai pengetahuan dan disiplin pajak yang tinggi, dimana ciri-ciri sistem self assessment adalah kepastian hukum, sederhana perhitungannya, mudah pelaksanaanya, lebih adil dan merata dan perhitungan pajak dilakukan oleh wajib pajak. ${ }^{15}$

\section{Kepastian Hukum Penetapan BPHTB Dalam Pelaksanaan Peralihan Hak Berkaitan dengan Kewajiban Estimasi dan Validasi BPHTB oleh Pemerintah Kota Bandung}

Pemungutan BPHTB adalah salah satu bagian yang sangat penting dalam proses peralihan hak (balik nama) atas tanah dan bangunan di Indonesia, karena Notaris dan Pejabat Pembuat Akta Tanah (PPAT) dilarang untuk menandatangani akta peralihan hak sebelum wajib pajak melunasi BPHTB sebagaimana mestinya, ${ }^{16}$ dan menurut Pasal 3 angka (4) huruf (h) Peraturan Pemerintah Republik Indonesia Nomor 55 Tahun 2016 Tentang Ketentuan Umum dan Tata Cara Pemungutan Pajak Daerah, bahwa BPHTB merupakan jenis pajak Kabupaten/Kota yang dibayar sendiri berdasarkan penghitungan oleh Wajib Pajak (self assessment).

Penentuan nilai transaksi dalam jual beli tanah dan/atau bangunan sudah diatur jelas dalam Pasal 87 ayat 1 Undang-Undang Nomor 28 Tahun 2009 Tentang Pajak Daerah dan Retribusi Daerah yaitu Dasar pengenaan BPHTB adalah Nilai Perolehan Objek Pajak, kemudian ayat 2 menjelaskan bahwa Nilai Perolehan Objek Pajak sebagai mana dimaksud pada ayat (1), dalam hal huruf (a): Jual beli adalah Harga Transaksi dan dalam Pasal 87 ayat (3) Jika Nilai Perolehan Objek Pajak sebagaimana dimaksud pada ayat (2) huruf (a) sampai

${ }^{15}$ Imam Nur Akbar, et.al., Pengaruh Persepsi Wajib Pajak Orang Pribadi Terhadap Pelaksanaan Self Assessment System, Jurnal Perpajakan (JEJAK) Vol. 7 No. 1, 2015, hlm. 4.

${ }^{16}$ Marihot Pahala Siahaan, Kompilasi Peraturan Di Bidang BPHTB, Panduan Dalam Penyusunan Aturan Pelaksanaan Peraturan Daerah Tentang BPHTB, Graha Ilmu, Yogyakarta, 2010, hlm.7. 
dengan huruf (n) tidak diketahui atau lebih rendah dari pada NJOP (Nilai Jual Objek Pajak Bumi dan Bangunan/ NJOP PBB) yang digunakan dalam pengenaan PBB pada tahun terjadinya perolehan, dasar pengenaan yang dipakai adalah NJOP Pajak Bumi dan Bangunan.

Dalam Pasal 91 ayat (1) Undang-Undang Nomor 28 Tahun 2009 Tentang Pajak Daerah dan Retribusi Daerah, bahwa Pejabat Pembuat Akta Tanah/Notaris hanyadapat menandatangani akta pemindahan Hak atas Tanah dan/atau Bangunan setelah Wajib Pajak menyerahkan bukti pembayaran pajak, bagi Pejabat Pembuat Akta Tanah/Notaris akan dikenakan denda sebesar Rp. 7.500.000,00 (Pasal 92 ayat (1) UU PDRD), sehingga dengan adanya verifikasi ini menghambat pekerjaan PPAT/Notaris, karena memperpanjang rantai pekerjaan PPAT/Notaris, sebetulnya tanpa dilakukannya verifikasi BPPD masih dapat melakukan penagihan atas kekurangan pajak apabila bukti dilapangan ditemukan adanya kekurangan pajak BPHTB, hal ini telah diatur dalam Pasal 97 ayat (1) huruf (a) butir (1) Undang-Undang Nomor 28 Tahun 2009 Tentang Pajak Daerah dan Retribusi Daerah, bahwa dalam jangka waktu 5 (lima) tahun sesudah saat terutangnya pajak, Kepala Daerah dapat menerbitkan: SKPDKB (Surat Ketetapan Pajak Daerah Kurang Bayar) dalam hal; jika berdasarkan hasil pemeriksaan atau keterangan lain, pajak yang terutang tidak atau kurang dibayar.

Prosedur verifikasi yang dilakukan oleh BPPD adalah untuk meneliti kebenaran data dan kelengkapan Surat Setoran Pajak Daerah Bea Perolehan Hak Atas Tanah dan Bangunan (SSPD BPHTB) dan dokumen pendukungnya dan dapat disertai dengan pemeriksaan lapangan. Hasil verifikasi akan diperoleh beberapa kemungkinan diantaranya adalah Nilai Perolehan Objek Pajak yang sebenarnya menjadi lebih rendah dari Nilai Perolehan Objek Pajak hasil verifikasi atau Nilai Perolehan Objek Pajak yang sebenarnya menjadi lebih tinggi dari Nilai Perolehan Objek Pajak hasil verifikasi.

Apabila SKPDKB tersebut masih belum dilakukan pembayaran oleh wajib pajak sebetulnya sudah diatur dalam Pasal 97 Ayat (5) Undang-Undang Nomor 28 Tahun 2009 Tentang Pajak Daerah dan Retribusi Daerah, bahwa Jumlah pajak yang terutang dalam SKPDKB sebagaimana dimaksud pada Pasal 
97 ayat (1) huruf (a) angka (3) Undang-undang PDRD dijelaskan akan dikenakan sanksi administrative berupa kenaikan sebesar 25\% (dua puluh lima persen) dari pokok pajak ditambah sanksi administrative berupa bunga sebesar 2\% (dua persen) sebulan dihitung dari pajak yang kurang atau terlambat dibayar untuk jangka waktu paling lama 24 (dua puluh empat) bulan dihitung sejak saat terutangnya pajak. Dalam hal permohonan menyampaikan data tidak sesuai dengan kenyataan dari hasil pemeriksaan lapangan itu, wajib pajak akan diminta untuk mengklarifikasi data tersebut, dan apabila wajib pajak tidak menerima hasil tersebut, Wajib Pajak wajib menyerahkan Surat Pernyataan untuk selanjutnya dimasukkan ke dalam sistem BPPD.

BPPD memberikan hak kepada wajib pajak untuk mempertahankan datadata yang disampaikan oleh waib pajak, dengan melampirkan surat pernyataan yang ditanda tangani oleh para pihak penjual dan pembeli, dan apabila dikemudian hari ditemukan data yang tidak cocok dengan pernyataan para pihak maka, wajib pajak akan dikenakan sanksi. Ada 2 (dua) macam Sanksi perpajakan yaitu sanksi administrasi dan sanksi pidana. Sanksi Administrasi terdiri dari sanksi administrasi berupa denda dan sanksi administrasi berupa bunga serta sanksi administrasi berupa kenaikan. Sanksi Pidana dalam perpajakan pada dasarnya merupakan upaya terakhir untuk meningkatkan kepatuhan Wajib Pajak. Akan tetapi pemerintah masih memberikan keringanan dalam pemberlakuan sanksi pidana dalam pajak, yaitu bagi Wajib Pajak yang baru pertama kali melanggar ketentuan Pasal 38 Undang-Undang KUP tidak dikenai sanksi pidana, tetapi dikenai sanksi administrasi.

Dalam hal surat pernyataan yang telah disiapkan format nya oleh BPPD (surat terlampir) pada saat pengajuan nota verifikasi, dalam surat tersebut menjelaskan mengenai apabila Wajib Pajak yang dengan sengaja tidak menyampaikan Surat Pemberitahuan Pajak Daerah (SPTPD) atau mengisi dengan tidak benar atau tidak lengkap atau melampirkan keterangan yang tidak benar sehingga merugikan keuangan Daerah, maka sesuai dengan Pasal 85 ayat (2) Peraturan Daerah Nomor 20 Tahun 2011 tentang Pajak Daerah, dapat dipidana dengan pidana penjara paling lama 2 (dua) tahun atau pidana denda 
paling banyak 4 (empat) kali jumlah pajak terutang yang tidak atau kurang bayar".

Jika kita melihat ketentuan Pasal 238 ayat (2) Undang-Undang Republik Indonesia Nomor 23 Tahun 2014 Tentang Pemerintahan Daerah dan Pasal 15 ayat (2) Undang-Undang Republik Indonesia Nomor 12 Tahun 2011 Tentang Pembentukan Peraturan Perundang-Undangan, dalam pasal tersebut dijelaskan bahwa Perda dapat memuat ancaman pidana kurungan paling lama 6 (enam) bulan atau pidana denda paling banyak Rp. 50.000.000,00 (lima puluh juta rupiah), sehingga sanksi pidana yang diterapkan dalam peraturan pemerintah daerah dengan undang-undang tidak ada keseragaman dan bertentangan dengan peraturan perundang-undang. Berdasarkan kedua undang-undang tersebut terlihat bahwa perumusan sanski pidana kurungan maupun pidana denda dalam Peraturan Daerah ditentukan dengan menggunakan sistem sanksi maksimum.

Ketentuan dalam Pasal 16 ayat (4) Peraturan Walikota Bandung Nomor 1405 Tahun 2016 tentang Kedudukan, Susunan Organisasi, Tugas dan Fungsi serta Tata Kerja Badan Pengelolaan Pendapatan Daerah Kota Bandung mengatur tugas dan fungsi serta tata kerja dari sub bagian BPHTB dalam hal salah satunya melaksanakan verifikasi, otorisasi, dan pembukuan lingkup BPHTB.

Sistem Self Assessment memberikan kepercayaan yang lebih besar kepada anggota masyarakat untuk melaksanakan kewajiban perpajakannya, memberikan jaminan hukum dan kepastian hukum mengenai hak dan kewajiban perpajakan bagi Wajib Pajak sehingga diharapkan dapat lebih merangsang peningkatan kesadaran dan tanggung jawab perpajakan dalam masyarakat. Sistem Self Assessment diharapkan dalam diri Wajib Pajak dapat tumbuh adanya:

1. Tax Consciousness (kesadaran dan kepatuhan);

2. Kejujuran;

3. Tax Mindedness (hasrat untuk membayar);

4. Tax Discipline yaitu disiplin Wajib Pajak terhadap pelaksanaan peraturanperaturan pajak sehingga pada waktunya Wajib Pajak dengan sendirinya memenuhi kewajiban-kewajiban yang dibebankan undang-undang 
kepadanya seperti memasukkan SPT pada waktunya, membayar pajak tanpa diperingatkan.

Kewajiban perpajakan pada hakekatnya merupakan kewajiban kenegaraan bagi masyarakat dalam kerangka pemikiran tentang keikutsertaan atau peran serta rakyat dalam pembiayaan negara maupun pembangunan nasional. Hal ini sangat penting untuk diupayakan agar lebih didasarkan pada kesadaran dan kepatuhan masyarakat yang timbul dan dirasakan oleh Wajib Pajak. Kewajiban perpajakan timbul karena perbuatan hukum/peristiwa hukum.

Aturan diterapkan oleh pemerintah Daerah terhadap pengenaan Bea Perolehan Hak atas Tanah dan Bangunan tersebut diterapkan harus mempertimbangkan terhadap asas-asas yang melandasi pemungutan pajak. Salah satunya adalah dasar pengenaan Bea Perolehan Hak Atas Tanah dan Bangunan sebagai dasar perhitungan pajak yang tidak mencerminkan prinsip certainty atau kepastian hukum yang harus ada dalam suatu peraturan.

Penetapan pajak harus jelas, tidak dilakukan secara sewenang-wenang, wajib pajak harus mengetahui secara jelas dan pasti besarnya pajak terutang, kapan harus dibayar, dan batas waktu pembayarannya. Pemungutan pajak yang jelas akan memberikan kepastian hukum terhadap hak dan kewajiban wajib pajak sehingga akan meningkatkan kesadaran wajib pajak.

\section{Simpulan}

1. Sistem pemungutan BPHTB oleh pemerintah Kota Bandung melalui BPPD Kota Bandung berdasarkan amanat UU 28 tahun 2009 tentang PDRD, dalam implementasinya menimbulkan adanya campur tangan pemerintah (official assessment system), dengan mengeluarkan nilai estimasi yang ditentukan di awal sebelum transaksi, hal ini bertentangan dengan asas praduga tidak bersalah yang menjadi filosofi self assessment system sehingga dengan demikian tidak adanya kesesuaian antara peraturan perundang-undangan yang ada dan bentuk implementasi dalam sistem self assessment itu sendiri. 
2. Kewajiban estimasi dan validasi oleh BPPD Kota Bandung menyebabkan tidak adanya kepastian hukum terhadap penentuan harga transaksi dan juga terhadap waktu penyelesaian dalam proses peralihan hak atas tanah dan bangunan, sehingga akan menimbulkan akibat hukum terhadap akta yang dibuat menjadi dapat dibatalkan. 


\section{DAFTAR PUSTAKA}

\section{A. Buku}

Adrian Sutedi, Hukum Pajak, Sinar Grafika, Jakarta, 2016.

Mardiasmo, Perpajakan Edisi 4, Andi, Yogyakarta, 1997.

Marihot Pahala Siahaan, Kompilasi Peraturan Di Bidang BPHTB, Panduan Dalam Penyusunan Aturan Pelaksanaan Peraturan Daerah Tentang BPHTB, Graha Ilmu, Yogyakarta, 2010. , Bea Perolehan Hak Atas Tanah dan Bangunan, Teori dan Praktik, PT. Raja Grafindo, Jakarta, 2005. , Bea Perolehan Hak Atas Tanah dan Bangunan Teori dan Praktik, Edisi Revisi, Rajawali Pers, Jakarta, 2003.

Mochtar Kusumaatmadja dan Lilian Tedjosaputro, Etika Profesi Dalam Penegakan Hukum Pidana, Bigraf Publishing, Yogyakarta, 1994. , Konsep-Konsep Hukum Dalam Pembangunan, Alumni, Bandung, 1995.

Rochmat Soemitro, Hukum Pengantar Singkat Pajak, Eresco, Bandung, 1992.

Rusdianto, Hukum Otonomi Daerah, Refika Aditama, Bandung, 2012.

Wiratni Ahmadi, et.al., Teknik Pembuatan Akta Notaris, Logoz Publishing, Bandung, 2016.

\section{B. Jurnal}

Adimas Wahyu Widayat, Analisis Pengenaan Bea Perolehan Hak Atas Tanah Dan Bangunan Dalam Proses Jual Beli Tanah dan Bangunan di Kabupaten Kebumen, Jurnal Lex Renaissance, Vol. 1 No. 2, Juli 2016.

Budi Ispriyaso, Aspek Perpajakan dalam Pengalihan Hak Atas Tanah dan/atau Bangunan karena Adanya Transaksi Jual Beli, Masalah-masalah Hukum, Volume 14, Mitra Bakti, 2005.

Imam Nur Akbar, et.al., Pengaruh Persepsi Wajib Pajak Orang Pribadi Terhadap Pelaksanaan Self Assessment System, Jurnal Perpajakan (JEJAK) Vol. 7 No. $1,2015$.

Tarjo dan Indra Kusumawati, Analisis Perilaku Wajib Pajak Orang Pribadi Terhadap Pelaksanaan Self Assessment System: Suatu Studi Di Bangkalan, JAAI Volume 10, No. 1 Juni 2006:.

Toyyibatuz Zaimah, Efektivitas Self Assessment Dalam Pajak Penghasilan di Kantor Pelayanan Pajak Pratama Batu (Perspektif Hukum Positif dan 
Hukum Islam), Jurusdictie: Jurnal Hukum dan Syariah Vol. 7 No. 1 Tahun 2016. 